\title{
Cotton Cloth: Diversified Applications beyond Fashion and Wearable Cloth
}

\author{
Suzylawati Ismail* and Syahida Farhan Azha \\ School of Chemical Engineering, Universiti Sains Malaysia, Engineering Campus, Penang, Malaysia
}

Submission: December 14, 2017; Published: January 23, 2018

*Corresponding author: Suzylawati Ismail, School of Chemical Engineering, Universiti Sains Malaysia, Engineering Campus, 14300 Nibong Tebal, Penang, Malaysia, Tel: +604-599 6458; Fax: +604-5996908; Email: chsuzy@usm.my

\begin{abstract}
Recent developments in the field of textile industry highlighting cotton cloth/fabric to a new interest in another application. The cotton cloth that is well known as one of the most comfortable wearable fabric has positioning itself to various new significant functions and application especially in the area of wastewater treatment technology, medical and surgery devices, electronic applications, enzyme and lipase production, crop and harvesting procedure, energy storage devices and etc. This article emphasizing few studies from various researches regarding the use of cotton cloth either as a substrate, template material, function modification or even as storage or covering materials. This proved the versatility of cotton cloth to be used in vast areas of technology.
\end{abstract}

Keywords: Cotton cloth; Cotton fabric; Cotton cloth substrate; Wearable cloth; Cotton cloth application

Abbreviations: GOS: Galacto-Oligo Saccharides; RGO: Reduced Graphene Oxide; ISTA: International Seed Testing Association

\section{Introduction}

Daily clothes such as blouses, T-shirts, sweater, robes, under garments and even sheets or blanket mainly originated from natural cotton fibers. Weaving activity of cotton fiber has produced a flexible and porous cotton fabric with soft yet strong, durable and comfort properties [1]. Cotton is suitable and matched with weather in Asia and perfect for wearing in the summer. Cotton cloth is one of the most popular fabrics to wear because of it many advantages. It definitely have a comfortable, wearable and breathable cloth, since it able to draw heat away from skin, easily absorb body moisture and evaporate in the air keeping cool and comfortable in hot weather $[2,3]$. Cotton fabric irregularly causes allergic responses and wearing cotton cloth is often suggested for those with skin allergic [3]. The medical product such as bandages and gauze also produced from cotton. In addition to that, cotton cloth is the best choice of fabric when it comes to baby/children clothing [2]. Cotton is allowing air circulation that discourages fungi from growing in dark and moist atmosphere [2,3]. The affordable cost of cotton cloth make more appealing and high in demand. Thus, cotton cloth with various advantages has make it a perfect choice for people nowadays to wear with coziness in daily life.

The rapid growth and exploration of emerging technology nowadays allows cotton cloth to be further explored, designed and manufactured for a broader spectrum of applications. A significant progress has been achieved through modified and improved it surface function, structure and morphology. For instances, it is applicable in wastewater treatment technology [4-6], medical and surgery devices [1], electronic applications [79], enzyme and lipase production $[10,11]$, in crop and harvesting procedure [12], energy storage devices [9] and the number keep increasing from one technology to another.

\section{Diversified cotton cloth application}

The specialty of cotton cloth includes less in weight, very flexible to be folded or recovered, thin in diameter sizes, good mechanical strength, and lower cost, have good breathability, abundance in nature, renewability, versatility and easily to get from any cloth shops around the world. The following describe the use of cotton cloth in another technology application.

The cotton cloth has been effectively used as a filter to remove radioactive ions such as uranium which mainly comes from nuclear industry. The synthesis of cotton cloth filter was grafted by acrylonitrile and methacrylic acid onto cotton cloth using mutual irradiation technique and the subsequent amidoximation of the reactive intermediate nitrile groups. The grafting on cotton/cellulose materials have several advantages due to high hydrophilicity, high adsorption capacity and fibrous structure of cellulosite material. Plus, this filter can be biodegraded after used 
and possesses good morphology and chemical stability which is suitable for practical application [13]. Figure 1 illustrates the
SEM image of cotton cloth filter fabricated to remove uranium ion from radioactive waste treatment.

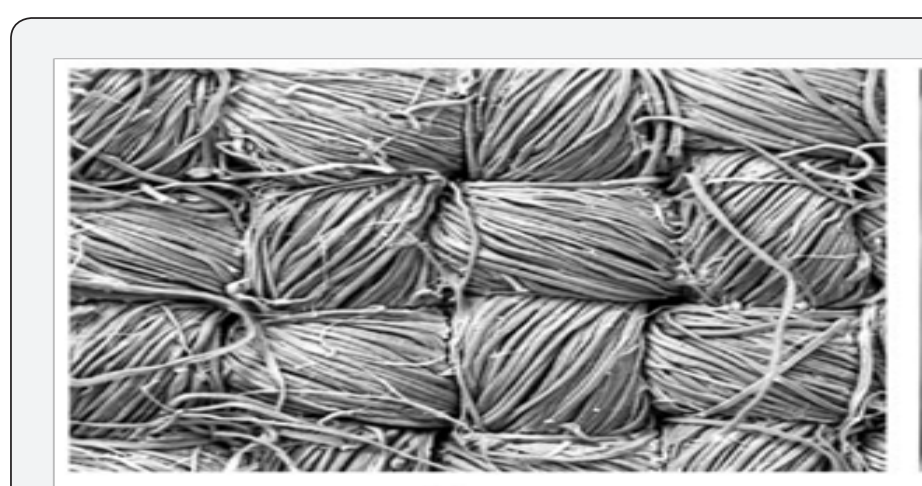

$75 \mathrm{X}, 0.27 \mathrm{~mm}$

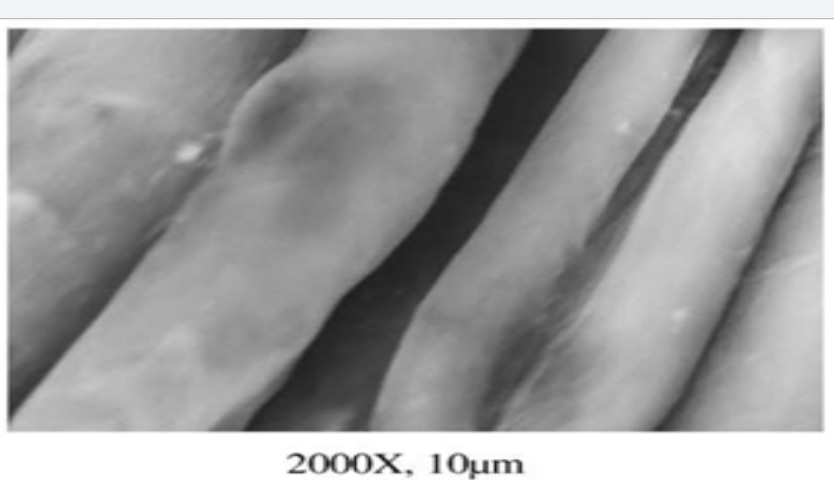

$2000 x, 10 \mu m$

Figure 1: SEM images of cotton cloth filter for the removal of uranium ion from radioactive waste treatment 13].

The enormous use of fossil fuels can cause severe consequences toward environment such as air pollution and global warming. In order to reduce the high reliance of fossil fuels, the expansion of high-performance electrochemical energy storage devices is required for renewable energy and electric vehicles. Energy storage devices will be highly in demand upon meeting criteria of flexible, lightweight, efficient, wearable or portable e.g.to be used in artificial biosensor or implantable medical devices. The cotton textile used as starting substance for constructing wearable super capacitors because of its low cost, high flexibility, great strength, good breathability, abundance, renewability and versatility [8]. Figure 2 shows the fabrication process of wearable super capacitor using cotton textile as substrate.

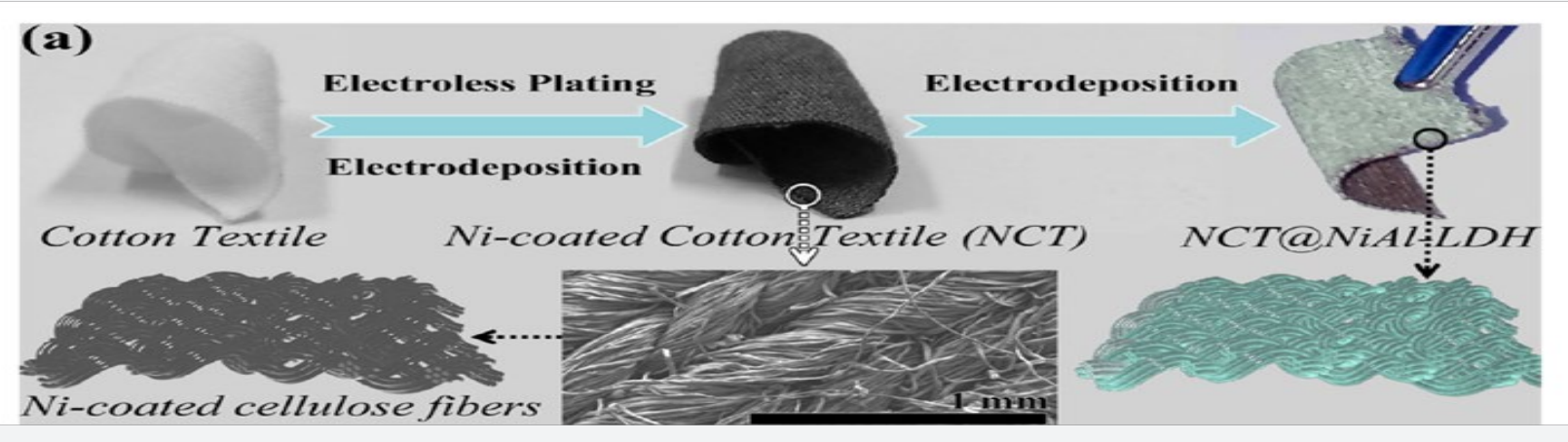

Figure 2: Schematic illustration of the fabrication process of wearable super capacitor using cotton textile as substrate [8].

Galacto-OligoSaccharides (GOS) production from lactose by $\beta$-galactosidase is introduced in food product and dairy industry due to many health benefits. Previous practice basically used free enzyme in solution for its production. However, compared with enzyme immobilizing on a solid support using reactor, it provides many advantages including enzyme reusability, operated continuously, controllable, simpler and efficient in processing. Besides, immobilized enzyme reactor generally more economic compare to free enzyme reactor due to higher productivity and able to minimize the downtime, enzyme costs and reactor size. With the used of cotton cloth packed in loose spiral form in the reactor, it has produce lower pressure drop, good flow rate and minimized the diffusion limitation [10]. In order to get clear understanding of enzyme cotton-cloth reactor, the schematic diagram is shown in Figure 3.

The lipase from thermo myceslanuginosus is a single chain protein with amino acid that produced enzyme. The enzyme is biotechnology relevant and is widely used in many industries such as food, fine chemicals, detergents, waste water treatment, cosmetics, paper and pulp, pharmaceuticals and leather industry. Cotton cloth as immobilization matrix has many advantages e.g. high porosity, large surface area, good mechanical strength and relatively inexpensive. It serves as an excellent choice as support matrix for immobilization [11]. 


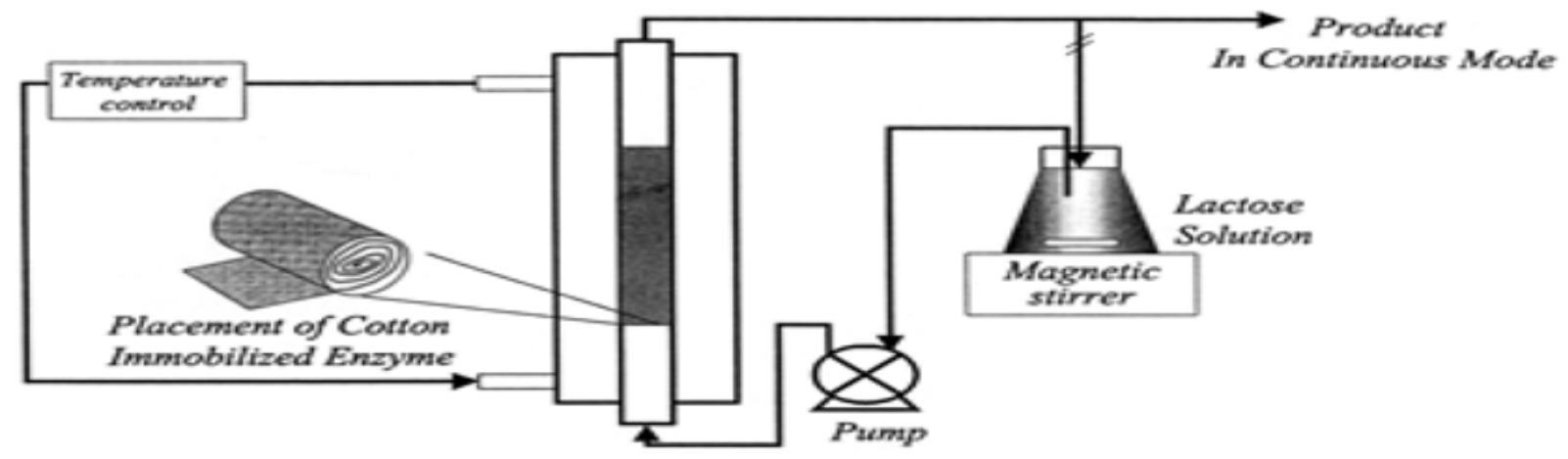

Figure 3: Schematic diagram of the immobilized enzyme cotton-cloth reactor [10].

Nanomaterial offer comprehensive potential applications when assimilated with fabric substrates such as to be used for heat generation application [14]. A study conducted using Reduced Graphene Oxide (RGO) nanosheets coated on cotton cloth based films as heating element for wearable body warmer. The fabric cloth coated nanomaterials being an interactive material for heating elements due to their special and exceptional properties such as large surface to volume ratio, less in weight, dimensionality, and corrosion free. Directly it minimizing the common problem faced by the device like heavyweight, inflexibility, and low heating proficiency. Hence, by considering all the advantages, the textile electronic devices can be employed in automobile, biomedical and electronic wearable technology. For example, the heating element application in biomedical field can be vast, for instances as medical blankets for patients, jacket for soldiers and electrotherapy treatment [1]. Figure 4 exhibits the fabricated RGO coated cotton cloth for heating element devices.

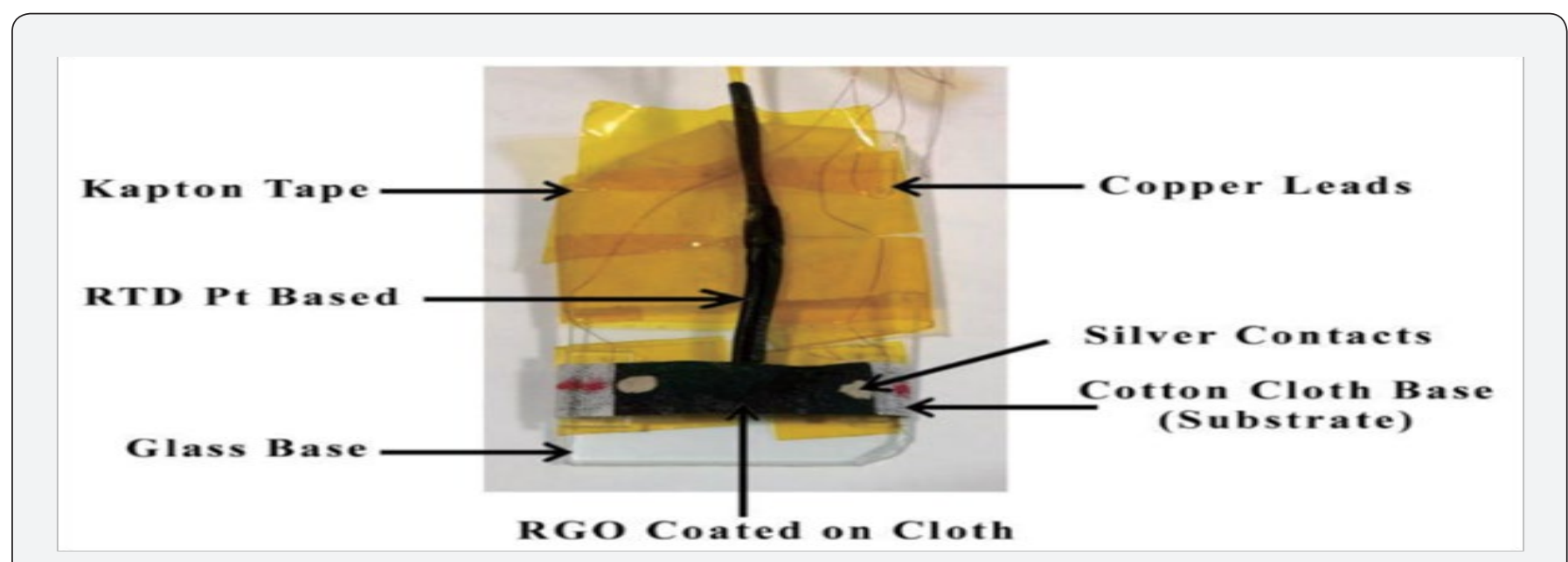

Figure 4: Image show the fabricated cotton cloth coated with RGO coated used for heating element devices [1].

Practically, microalgae cultures are sustained using a variety of techniques which include serial subculture, lyophilisation and cryopreservation. The maintenance and conservation of microalgae are tedious and require specific conditions. Due to several limitations, researchers have developed an easy and convenient method for long-term preservation and conservation of microalgae which is by using cotton fabric for the immobilization of microalgae [15]. Figure 5 presents the culture of microalgae immobilized on cotton cloth and SEM image of algal cell. 

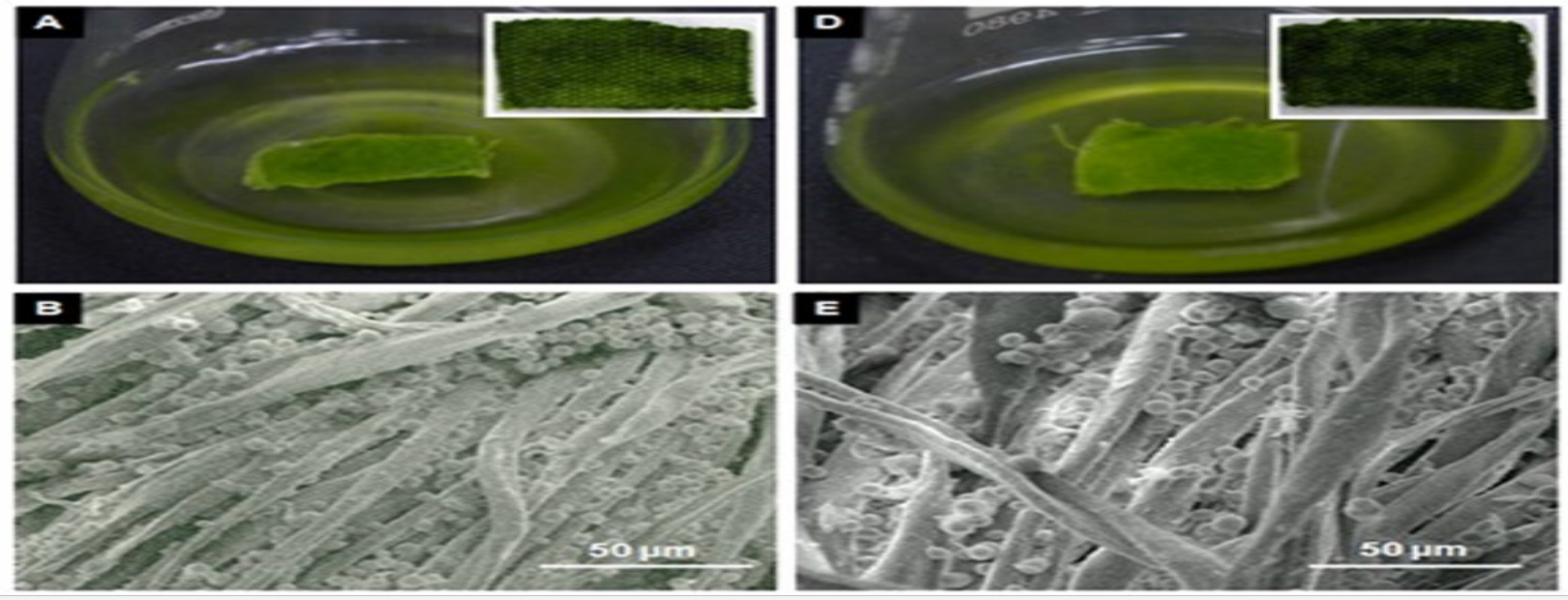

Figure 5: Cultures of microalgae (A) Chlorella minutissima (D) Chlamydomonas sp. With cotton cloth pieces, exhibite the immobilization of microalgae cell. $(B)$ and $(E)$ the SEM images of cotton cloth with immobilized algal cells [15].

Sorghum (Sorghum bicolor L.) is in forth ranking of cereal crop in the world after wheat, rice and maize. It is a tropical crop which belong to a grass family. In Tanzania, Sorghum is one of the most important source of subsistence in their country. For common practice, sorghum seed germination test has to be conducted using International Seed Testing Association (ISTA) paper substrate. The ISTA paper has to be imported since it was not manufactured in their country. As an alternative solution, cotton cloth is used as a substrate since the seed germination performance can be maintained similar to the use of ISTA paper. The cotton cloth has minimized the cost of importing ISTA paper due to local availability and lower in price [16]. Figure 6 shows the Sorghum seedlings laboratory germination tests using cotton cloth and ISTA paper.

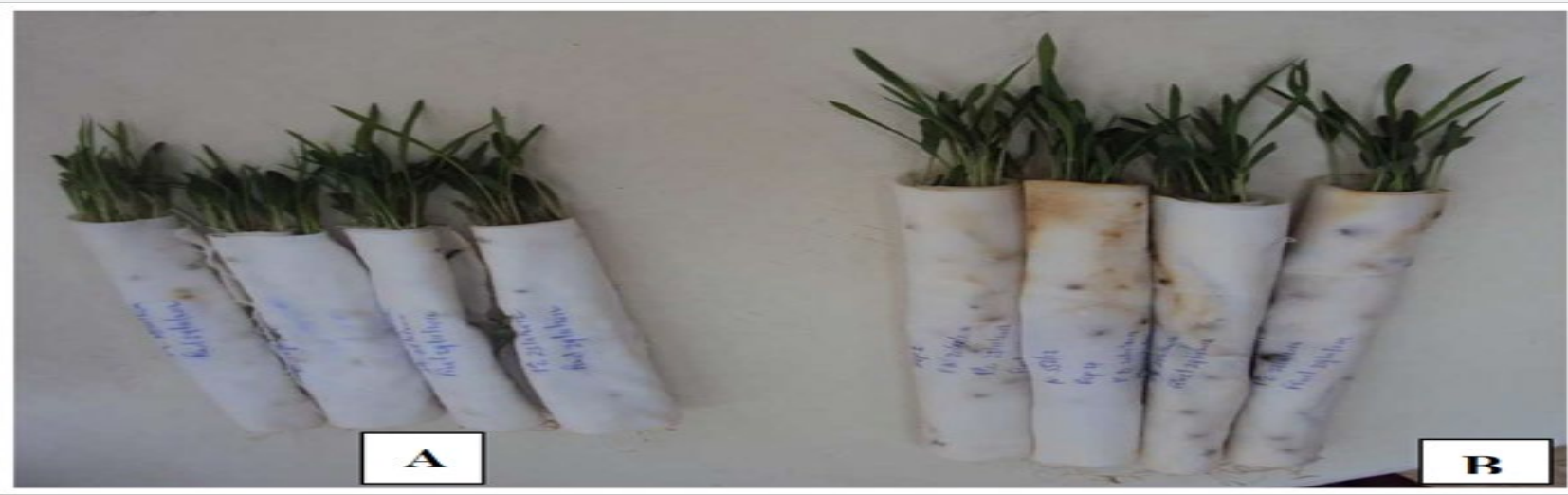

Figure 6: Cotton cloth (A) and ISTA paper (B) used in Sorghum seedlings laboratory germination tests [12].

The use of cotton cloth is also diversified and tested for wastewater treatment technology. Focusing on effluent from textile and other dyeing industries such as paper, printing, leather, food and plastic industries, the presence of dyes create an environmental problem due to their high visibility, resistance and toxic impact [17]. Dyes can be eliminated by various methods, and most common method used is adsorption. Researchers coated the adsorbent on the cotton cloth as a substrate. The aim is to simplify the maintenance activity after the adsorption process as well as improving the surface area to weight ratio of the adsorbent and minimizing the quantity of solid adsorbent required. The cotton cloth was chosen as substrate due to its large surface area, thin, light weight, easy to handle and reasonable in price [18]. Figure 7 illustrates the cotton cloth adsorbent coating strip. 


\section{Current Trends in Fashion Technology \& Textile Engineering}

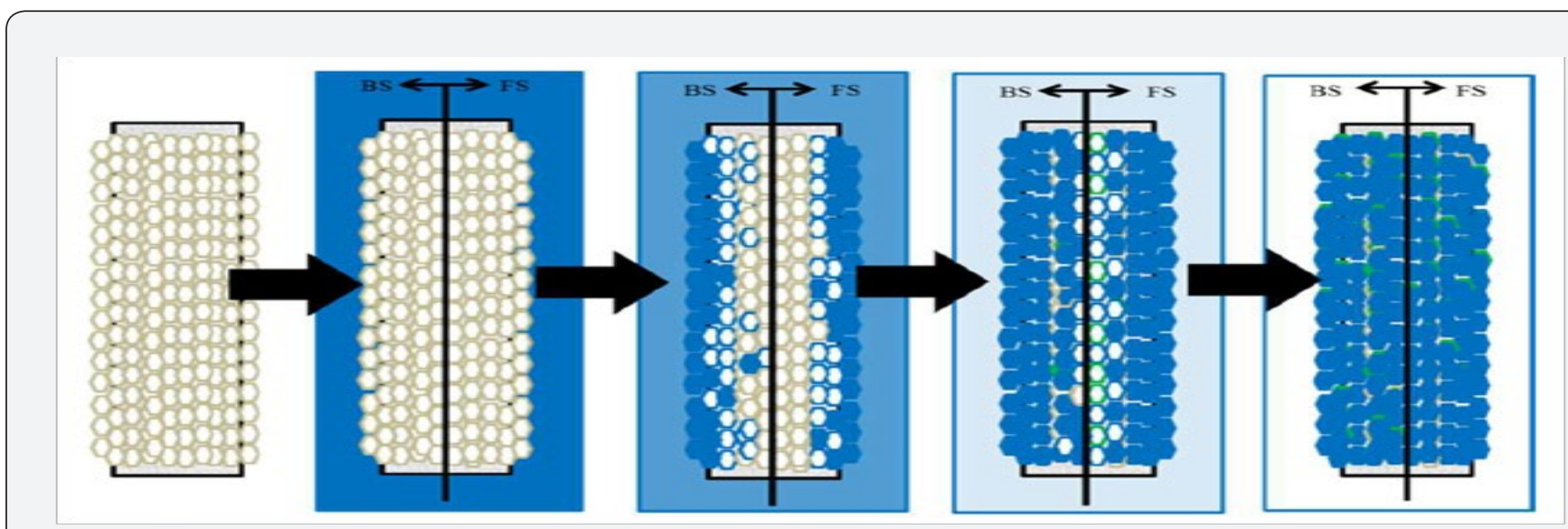

Figure 7(A): Illustration of adsorption process flow from adsorbent coating strip coated cotton cloth for the Methylene Blue dye removal from aqueous solution from time to time,

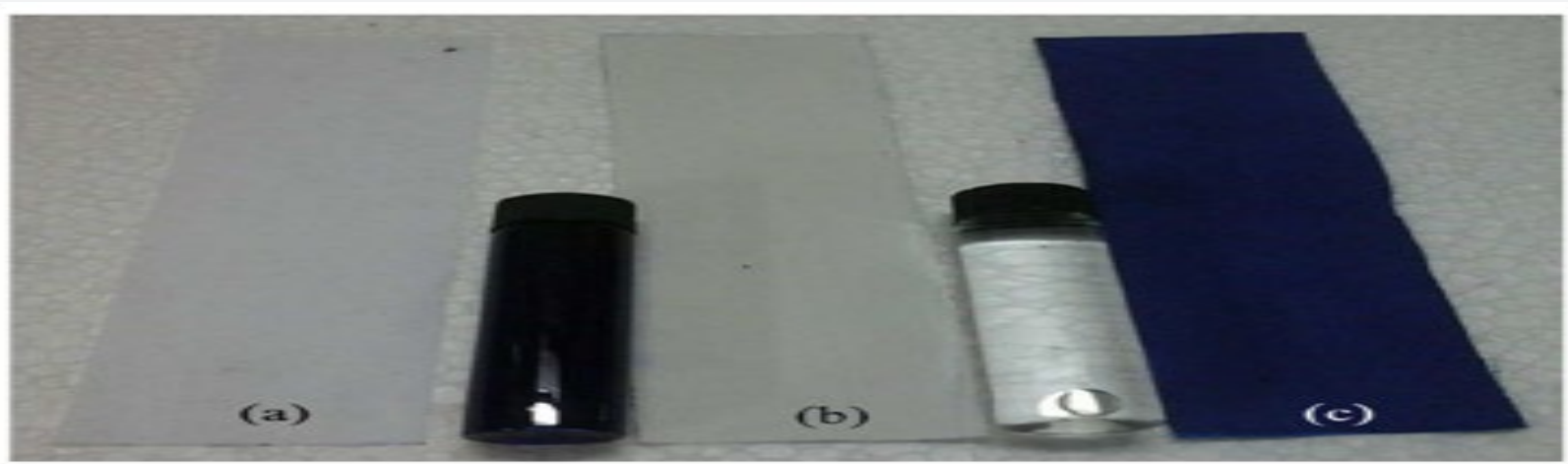

Figure 7(B): (a) bare cotton cloth, (b) adsorbent coating strip with Methylene Blue dye (in bottle), (c) adsorbed striped with clear water after adsorption (in bottle) [6].

A brief summary on the usage, function and advantages of cotton cloth in various field of applications is tabulated in Table 1.

Table 1: Summary of usage, function and advantages of cotton cloth in various field of application.

\begin{tabular}{|c|c|c|c|c|}
\hline $\begin{array}{r}\text { Field of } \\
\text { Application }\end{array}$ & Usage & Function of Cotton Cloth & Advantages of Cotton Cloth & Sources \\
\hline \multirow{4}{*}{$\begin{array}{l}\text { Wastewater } \\
\text { treatment }\end{array}$} & $\begin{array}{c}\text { Low-level } \\
\text { radioactive waste } \\
\text { treatment }\end{array}$ & Cotton cloth filter & $\begin{array}{l}\text { High hydrophilicity, high adsorption } \\
\text { capacity and fibrous structure }\end{array}$ & [13] \\
\hline & $\begin{array}{c}\text { Oil-absorption } \\
\text { material for water / } \\
\text { oil mixture separation }\end{array}$ & $\begin{array}{r}\text { Cotton was modify to } \\
\text { be superhydrophobic and } \\
\text { superoleophilic properties. }\end{array}$ & $\begin{array}{l}\text { Softness, flexibility, environmental } \\
\text { friendly, biodegradability }\end{array}$ & [16] \\
\hline & $\begin{array}{l}\text { Heavy metal } \\
\text { adsorbent }\end{array}$ & Waste cotton fabric & $\begin{array}{l}\text { 3-D porous structure, sheet-like } \\
\text { lamilar cellulose network offer promising } \\
\text { heavy metal removal, fast kinetic, } \\
\text { large adsorption capacities, reversible } \\
\text { adsorption properties. }\end{array}$ & {$[4]$} \\
\hline & Dyes removal & Adsorbent coating substrate & $\begin{array}{l}\text { Low cost, flexible, great strength of } \\
\text { adsorbent to be coated, good mechanical } \\
\text { strength }\end{array}$ & [6] \\
\hline
\end{tabular}




\section{Current Trends in Fashion Technology \& Textile Engineering}

\begin{tabular}{|c|c|c|c|c|}
\hline \multirow{3}{*}{$\begin{array}{c}\text { Energy } \\
\text { storage device }\end{array}$} & $\begin{array}{c}\text { High- } \\
\text { performance } \\
\text { Electrochemical } \\
\text { Energy Storage } \\
\text { devices (EES)/ } \\
\text { current collector/ } \\
\text { wearable super } \\
\text { capacitor }\end{array}$ & $\begin{array}{l}\text { Starting material for the } \\
\text { assembly of wearable super } \\
\text { capacitor }\end{array}$ & $\begin{array}{l}\text { Low cost, high flexibility, great } \\
\text { strength, good breathability, abundance, } \\
\text { renewability and versatility }\end{array}$ & [8] \\
\hline & $\begin{array}{l}\text { Wearable } \\
\text { electronic and Energy } \\
\text { storage device }\end{array}$ & $\begin{array}{l}\text { Cotton cloth as platform, flexible } \\
\text { and easy processing electrode }\end{array}$ & Prepare flexibility, thin, light weight & [9] \\
\hline & $\begin{array}{l}\text { Electrochemical } \\
\text { capacitor electrode }\end{array}$ & $\begin{array}{c}\text { Serve as 3-D binder-free } \\
\text { and flexible scaffold to anchor } \\
\text { nanostructure material }\end{array}$ & $\begin{array}{l}\text { High mass loading, tunable } \\
\text { morphology, high surface area }\end{array}$ & [7] \\
\hline \multirow{2}{*}{$\begin{array}{l}\text { Enzyme } \\
\text { and lipase } \\
\text { production }\end{array}$} & $\begin{array}{c}\text { Lipase } \\
\text { bimolecular } \\
\text { aggregation to } \\
\text { form multi layers of } \\
\text { enzyme. }\end{array}$ & $\begin{array}{c}\text { Support matrix for } \\
\text { immobilization of lipase. }\end{array}$ & $\begin{array}{l}\text { high porosity, large surface area, } \\
\text { good mechanical strength and relatively } \\
\text { inexpensive }\end{array}$ & {$[11]$} \\
\hline & $\begin{array}{l}\text { A. oryzae } \\
\text { B-galactosidase } \\
\text { for Galacto- } \\
\text { OligoSaccharides } \\
\text { (GOS) production } \\
\text { from lactose } \\
\end{array}$ & $\begin{array}{l}\text { Support matrix for enzyme } \\
\text { immobilization }\end{array}$ & $\begin{array}{l}\text { High porosity, large specific surface } \\
\text { area, low pressure drop, good flow rate, } \\
\text { little diffusion limitation, high mechanical } \\
\text { strength, inexpensive support }\end{array}$ & {$[10]$} \\
\hline \multirow{3}{*}{$\begin{array}{l}\text { Cotton } \\
\text { surfaces } \\
\text { modification }\end{array}$} & $\begin{array}{l}\text { Antimicrobial } \\
\text { cotton textile }\end{array}$ & $\begin{array}{l}\text { Modify surface material into } \\
\text { antimicrobial and antifouling } \\
\text { properties. }\end{array}$ & $\begin{array}{l}\text { Antibacterial and antifouling } \\
\text { cotton fabric, mechanical properties, } \\
\text { hydrophilicity and air permeability of } \\
\text { fabric improved after finishing, no skin } \\
\text { stimulation toxicity. }\end{array}$ & [17] \\
\hline & $\begin{array}{l}\text { Fabricating } \\
\text { superhydrophobic } \\
\text { coating }\end{array}$ & $\begin{array}{l}\text { Effective to separate oil/water } \\
\text { mixture }\end{array}$ & $\begin{array}{l}\text { Demonstrate intrinsic porous, rough, } \\
\text { flexible and hydrophilic surface with high } \\
\text { absorption ability }\end{array}$ & [18] \\
\hline & $\begin{array}{c}\text { RGO coated } \\
\text { cotton cloth based } \\
\text { film as heating } \\
\text { element for wearable } \\
\text { body warmer } \\
\text { application } \\
\end{array}$ & Cotton cloth as substrate & $\begin{array}{l}\text { Light weight, corrosion free and } \\
\text { chemical stability, can be employed } \\
\text { in biomedical, automobile, flexible } \\
\text { electronics for wearable technology }\end{array}$ & [1] \\
\hline $\begin{array}{l}\text { Algae } \\
\text { storage }\end{array}$ & $\begin{array}{l}\text { Apt storage } \\
\text { and conservation/ } \\
\text { preservation of } \\
\text { microalgal cells }\end{array}$ & Immobilizing on cotton cloth & $\begin{array}{l}\text { Can store for a long time and } \\
\text { effectively revived. Algal cultures } \\
\text { preserved using this method can be } \\
\text { transported with ease across the world. }\end{array}$ & [15] \\
\hline $\begin{array}{l}\text { Crop and } \\
\text { harvesting } \\
\text { procedure }\end{array}$ & $\begin{array}{c}\text { Laboratory } \\
\text { Sorghum (tropical } \\
\text { crop belong to grass } \\
\text { famiy) germinating } \\
\text { test }\end{array}$ & $\begin{array}{l}\text { The sorghum was placed apart } \\
\text { on moist cotton cloth substrate and } \\
\text { then were rolled. }\end{array}$ & $\begin{array}{l}\text { To minimize cost of importing other } \\
\text { paper, locally available, low price }\end{array}$ & {$[12]$} \\
\hline
\end{tabular}

\section{Conclusion}

The current study contributes to our knowledge by addressing several issues.

o Cotton cloth has been used extensively in many areas other than apply in fashion and wearable cloth, it is also included in wastewater treatment, energy storage devices, crop and harvesting procedure, enzyme and lipase production.

o Cotton cloth have a variety of unique features and versatile include light weight, environmental friendly, biodegradability, good mechanical strength, high flexibility, good breathability, abundance, renewability, high porosity, large surface area, relatively inexpensive, locally available, no skin stimulation toxicity, broad chemical modification capacity and etc.

o Thus, this have given a big opportunity for the textile industries to manufacture and supplied more fabric as demand. Further explorations of cotton cloth for other promising arenas are expected with more advances and beneficial for the mankind.

\section{Acknowledgement}

The authors would like to acknowledge the Research University Grant (1001/PJKIMIA/814269) and Kementerian Pengajian Tinggi for providing My PHD as financial support 
throughout the study.

\section{References}

1. Neella N, Gaddam V, Rajanna K, Nayak MM (2017) “Low cost, disposable and wearable body warmer using RGO sheets coated on cloth substrate as heating element," 2017 IEEE $12^{\text {th }}$ Int. Conf. Nano/Micro Eng. Mol. Syst. NEMS 2017, pp. 177-180.

2. William Peterman (2017) "The Advantages of Cotton Clothing," Livestrong.com.

3. Hilary White (2017) "Advantages and Disadvantages of Cotton Cloth," Livestrong.com.

4. Ma J, Yutang Liu, Omar Ali, Yuanfeng Wei, Shuqu Zhang, et al., (2017) Fast Adsorption of Heavy Metal Ions by Waste Cotton Fabrics Based Double Network Hydrogel and Influencing Factors Insight. J Hazard Mater pp. 1034-1042.

5. Azha SF, Shahadat M, Ismail S (2017) Acrylic polymer emulsion supported bentonite clay coating for the analysis of industrial dye. Dyes and Pigments 145: 550-560.

6. Azha SF, Hamid SA, Ismail S (2016) Development of Composite Adsorbent Coating Based Acrylic Polymer/bentonite for Methylene Blue Removal. J Eng Tec Sci 49(2): 225-235.

7. Zhang Y, Mao T, Cheng L, Wu H, Wu R, et al. (2017) Tunable morphology and property of a $\mathrm{MnO}_{2}$ /carbonized cotton textile hybrid electrode for electrochemical capacitors. J Alloys Compd 729: 655-662.

8. Lu H, Chen J, Tian Q (2018) Wearable high-performance super capacitors based on $\mathrm{Ni}$-coated cotton textile with low-crystalline $\mathrm{Ni}$ Al layered double hydroxide nanoparticles. J Colloid Interface Sci 513: 342-348.

9. Wen-wen Liu QX, Xing-bin Yan, Jun-wei Lang, Chao Peng (2012) Flexible and Conductive Nanocomposite Electrode Based on Graphene sheets and Cotton Cloth for Supercapacitor Wen-wen J Mater Chem Chem no. 207890

10. Albayrak N, Yang ST (2002) Production of galacto-oligosaccharides from lactose by Aspergillus oryzae?-galactosidase immobilized on cotton cloth. Biotechnol Bioeng 77(1): 8-19.

11. Karimpil JJ, Melo JS, D’Souza SF (2012) Immobilization of lipase on cotton cloth using the layer-by-layer self-assembly technique. Int J Biol Macromol 50(1): 300-302.

12. Mamiro DP, Clement GH, Msemwa JI, Swai MM (2015) Performance of cotton cloth substrates in laboratory sorghum seeds germination tests. 5(6): 1-7.

13. Othman SH, Sohsah MA, Ghoneim MM (2009) The effects of hazardous ions adsorption on the morphological and chemical properties of reactive cloth filter. Radiat Phys Chem 78(11): 976-985.

14. Qu X, Alvarez PJJ, Li Q (2013) Applications of nanotechnology in water and wastewater treatment. Water Res 47(12): 3931-3946.

15. Prasad R, Shabnam N, Pardha-Saradhi P (2016) Immobilization on cotton cloth pieces is ideal for storage and conservation of microalgae. Algal Res 20: 172-179.

16. Liu F, Ma M, Zang D, Gao Z, Wang C (2014) Fabrication of superhydrophobic/superoleophilic cotton for application in the field of water/oil separation. Carbohydr Polym 103: 480-487.

17. Zhang S, Yang X, Tang B, Yuan L, Wang K, et al. (2017) New insights into synergistic antimicrobial and antifouling cotton fabrics via dually finished with quaternary ammonium salt and zwitterionic sulfobetaine. Chem Eng J.

18. Das I, De G (2015) Zirconia based superhydrophobic coatings on cotton fabrics exhibiting excellent durability for versatile use. Sci Rep 5: 1-11.

This work is licensed under Creative

Commons Attribution 4.0 Licens

DOI: 10.19080/CTFTTE.2018.02.555587
Your next submission with Juniper Publishers will reach you the below assets

- Quality Editorial service

- Swift Peer Review

- Reprints availability

- E-prints Service

- Manuscript Podcast for convenient understanding

- Global attainment for your research

- Manuscript accessibility in different formats

( Pdf, E-pub, Full Text, Audio)

- Unceasing customer service

Track the below URL for one-step submission

https://juniperpublishers.com/online-submission.php 